\title{
REPLACEMENT OF URBAN SPACE: ESTONIAN POST-WAR TOWN PLANNING PRINCIPLES AND LOCAL STALINIST INDUSTRIAL TOWNS
}

\author{
Siim SULTSON \\ Department of Architecture and Urban Studies, Faculty of Civil Engineering, \\ Tallinn University of Technology, Tallinn, Estonia \\ E-mail:siim.sultson@eek.ee
}

Received 29 February 2016; accepted 7 October 2016

\begin{abstract}
The presented paper focuses on Estonian urban space research concerning both replacement of urban heritage and establishment of new urban design within the period of mid 1940s and 1950s. On the one hand, Stalinist principles brought by Soviet occupation reminded independent Estonian 1930s town planning ambitions. On the other hand, the new principles formulated a new paradigm that was unfamiliar to local urban space tradition. Estonian urban space was compelled to follow the Soviet doctrine by concept, forms and building materials. Sometimes suffering irrational demolitions the towns got axially arranged representative, but perspective and functional plans. Some existing towns (for instance Tallinn, Pärnu, Narva) got new centres due to war wreckages and the ideological reasons. Meanwhile new industrial towns as examples of Stalinist utopia were built in East-Estonia during 1940s-1950s in order to exploit local mineral resources by the Soviet regime. In comparison with Tallinn and Pärnu urban space of East-Estonian industrial towns Kohtla-Järve and classified Sillamäe - designed in Leningrad (St. Petersburg) - still need to be researched. Though different from the rest of Estonian towns by details and materials of façades city-like centres of Sillamäe and Kohtla-Järve are rather similar to Tallinn and Pärnu by their composition.
\end{abstract}

Keywords: urban design research, architecture, production of space, urban space, town planning, representing the state, ideology, Stalinism

\section{Introduction}

Town planning and city space within it may be taken somehow as information communication technology. There one can recognize information recording functions (materialized ideology), communicational functions (massive, seemingly for one purpose, a produced space) and procession functions (computing and again communicating ideology via material). Public architecture communicates with everyone, but especially via grandiose and ensemble-like buildings as memory or ideology carriers. Thus public architecture, e.g. city space has always been beloved by authoritarian and totalitarian systems in order to control citizens, their minds and memory.

According to the official Stalinist consideration the Soviet town planning and urban space was supposed to oppose the Western one, to demonstrate preferences of the socialist practice compared the capitalist one. Current Estonian Stalinist urban space research is either affected by the similar tendencies (though in much moderate way) or reduced to simple narration of the period. Current analysis of Estonian post-war city planning and urban space has mostly consisted of juxtaposition of graphic material, buildings without penetrating the issue - whence and why everything has come, what were the reasons, what was the context. Merely comparing projects and houses is not enough since the buildings trying to embody the ideology are still fragments of the wider paradigm. Due to the fact Sillamäe and Kohtla-Järve (in the first stage) are not planned by local architects (e.g. the documents are in Russian, many documents are presumably in Russia etc.), their appearance differ appearance of the rest of Estonian towns' Stalinist appearance the East-Estonian Stalinist industrial towns are still considered different, unfamiliar, exotic, as from parallel dimension in Estonia. Urban spaces of East-Estonian towns Sillamäe and Kohtla-Järve are under-researched. 
It is important to include and incorporate the EastEstonian industrial towns into research of Estonian post-war Stalinist urban space due to their location in the Republic of Estonia, thus the towns are a part of local urban space history. Regardless the above mentioned facts characterising so-called unfamiliarity of the East-Estonian towns Stalinist centres of Kohtla-Järve and Sillamäe have architectural and urban compositional similarities and connections with Stalinist centres of Tallinn and Pärnu. The Department of Architecture of the Estonian SSR and its head Harald Arman that processed masterplans and construction plans of all local towns were familiar with masterplans and construction plans of both industrial towns already in mid1940s (ERA.R-1992.2.12: 44-54; ERA.R-1992.2.1; ERA.R-1992.2.31; ERA.R-1992.2.22; ERA.R-1992.2.41). Research of Estonian post-war urban space is incomplete without related deeper and complex knowledge of the East-Estonian industrial towns that for instance helps to define post-war urban space of Tallinn and Pärnu more adequately. The Stalinist period is a part of Estonian history, deeper knowledge of the period helps to define the perspectives of the state and its inhabitants. Since urban space research is architectural issue as well as social issue (how to use and develop the urban heritage) deeper and complex knowledge of the East-Estonian industrial towns helps to integrate mostly Russian-speaking North-East Estonia into the entire state and support improvement of the area. The port of Sillamäe is being situated nearby border of the Russian Federation and is the easternmost commercial port of the European Union.

Object of the presented paper is research of Estonian post-war urban space and its approach to local Stalinist industrial towns.

Methodology of the paper is qualitative and it is focused on ideology of town planning.

Objective of the paper is to analyse research of Estonian post-war urban space from point of view of replacement of urban heritage and establishment of new urban design according to the ideology currently in force both taking Tallinn and Pärnu as examples and local Stalinist industrial towns (Sillamäe and KohtlaJärve) within the period of mid 1940s and 1950s. The four towns are taken as examples since all of them have the most complex Stalinist urban centers.

Tasks of the paper are:

- to present the state of research of Estonian post-war urban space;

- to outline some contradictories and deficiencies in research of Estonian post-war urban space (familiar and/vs unfamiliar);

- to show formation of Estonian post-war Stalinist urban space on the one hand taking Tallinn and
Pärnu as examples and on the other hand in EastEstonian industrial towns;

- to outline similarities of Estonian post-war Stalinist urban space in Tallinn and Pärnu and in Sillamäe and Kohtla-Järve;

- to include and incorporate East-Estonian industrial towns into research of Estonian post-war Stalinist urban space as an inseparable issue of research.

\section{Present state of research of Estonian post-war urban space}

While in 1940s-1950s, even later within the Soviet era simplified consideration of the issue may be regarded understandable, the similar consideration, though much more loose, up to nowadays is somehow still in use.

In literature overview concerning the topic one can define three periods: the contemporaneous Stalinst period (mid1940s-mid1950s), the post-Stalin Soviet period (mid1960s-1980s) and the modern period (early1990s-nowadays).

In the contemporaneous Stalinist period within mid1940s-mid1950s current Soviet town planning and urban space were considered in professional periodical publications like "ENSV Arhitektide Almanahh" $(1946,1948,1949,1951)$. Those articles on the one hand were informative concerning ongoing town planning, on the other hand, while containing analyses of the issue, stately ideological. For instance one could follow articles concerning masterplans of existing and future towns, urban space, urban ensemble by the head of the Department of Architecture of the Estonian SSR and architect Harald Arman (Arman 1946, 1948, 1949), as well as by architects Ernst Ederberg (Ederberg 1946, 1948), Lorenz Haljak (Haljak 1949), Otto Keppe (Keppe 1951), Voldemar Meigas (Meigas 1948, 1949), Anton Soans (Soans, Keppe 1946; Soans 1949), Ivan Starostin (Arman, Starostin 1951). The similar conceives could be found Harald Arman's book “Tuleviku-Tallinn. Eesti NSV Poliitiliste ja Teadusalaste Teadmiste Levitamise Ühing 1 (45)" (Future Tallinn. Society for Spreading of Knowledge of Politics and Science 1 (45)) (Arman 1950) and article "Voprosy planirovki i zastrojki centra Tallina" (Questions concerning planning and building-up of Tallinn) (Arman 1955). One could find similar concepts from newspapers ("Sirp ja Vasar", "Sovetskaja Estonija”, "Rahva Hääl”, “Õhtuleht”, "Postimees”).

After Joseph Stalin's death the era urban space nor town planning seemed no popular. There are merely some attempts within general books in the postStalin Soviet period literature. For instance, in 1965 book "Eesti arhitektuuri ajalugu" (History of Estonian Architecture, edited by H. Arman et al.) (1965) the issue 
is considered in rather neutral, protocolling way. The same consideration is visible in architect Paul Härmsons article about Pärnu (1983).

Due to regained independence and opportunity to analyse the topic objectively one can see several representations in the modern period. Historian of architecture Leonid Volkov, contemporaneous of Stalin era, published an article "Eesti arhitektuurist aastail 1940-1954" (About Estonian architecture within 19401954) in 1991 (Volkov 1991). Former Chief Architect of Tallinn (1960-1980) Dmitri Bruns considered Stalinist town planning of Tallinn in his book "Tallinn: linnaehituslik kujunemine" (Tallinn: Urban Formation) in neutral protocolling manner (Bruns 1993). Historian of architecture Mart Kalm considered the issue as an architectural background in his monography "Alar Kotli" (Kalm 1994) and in his book "Eesti 20. sajandi arhitektuur" (Estonian $20^{\text {th }}$ Century Architecture) (Kalm 2001, 2003). In both books M. Kalm centres onto architectural and architects' personal details without giving complex structured definition of the Estonian post-war urban space and separates so-called local urban space (Tallinn, Pärnu) and so-called non-local urban space (Kohtla-Järve, Sillamäe). The trend defines the Estonian post-war urban space as consisting of so-called familiar and so-called un-familiar issues. His articles "The Sovietization of Baltic Architecture" (Kalm 2003) and "Perfect Representations of Soviet Planned Space. Mono-industrial towns in the Soviet Baltic Republics in the 1950s-1980s" (Cinis et al. 2008) consider the Estonian post-war urban space similarly, but a more analytically. Estonian Stalinist town planning and urban space are considered in master thesis' of Siim Sultson (2002), Maria Orlova (2003) and Epp Lankots' article (2004) and S. Sultson's articles (Sultson 2003, 2013, 2014a, 2014b, 2015). However, the abovementioned texts, articles consider Estonian post-war urban space as an issue separated from East-Estonian Stalinist urban space.

In order to understand the fundamentals and mechanisms of the era, the town planning and urban space produced within the period it is inevitable to decode the latter one philosophically concerning relations between city space, power and representation. Only then it could be possible to define urban space both of the East-Estonian industrial towns and of the same area urban space in the rest of Estonia.

In order to analyse city planning of East-Estonian industrial towns, to define their typology, to discover and implement their potentiality in the field of urban space it is necessary to establish a theoretical basis for understanding urban space of the era. The theoretical basis is supposed to be integrated with sociology, symbolism of architecture, power and its necessity for representation.

Current Estonian research of Stalinist urban space tends to simplification, regarding the issue as something merely opposing to Western experience.

Regarding all those considerations it is possible to highlight that while Stalinist town planning and urban space of Tallinn and Pärnu are researched and documented quite well, the same issues of East-Estonian industrial towns Sillamäe and Kohtla-Järve have not met consideration in equal amount. One of the main reasons could be that all abovementioned considerations lack a philosophical approach for establishing a theoretical basis for understanding urban space of the era.

Consequently, as stated above, to analyse city planning of East-Estonian industrial towns, to define their typology, to discover and implement their potentiality in the field of urban space it is necessary to establish a theoretical basis for understanding urban space of the era. That theoretical basis encompassing urban space is supposed to be integrated with sociology, symbolism of architecture, power and its necessity for representation for instance via philosophical considerations written by Henry Lefebvre (Lefebvre 1991), Michael Foucault (Foucault 2000a, 2000b), Nelson Goodman (Goodman 1985) etc. The basis helps to define and position East-Estonian industrial towns as phenomena, as well in connection with the rest of Estonian Stalinist town planning and urban space. Moreover, that theoretical basis could help to redefine Estonian Stalinist town planning and urban space through East-Estonian industrial towns.

Historian of architecture Vladimir Paperny stated “... once Stalinist architecture becomes the centre of attention, however, the researcher no longer has the right to limit him- or herself to noting this or that borrowed element or echo of a European style; rather attention should be paid to how they are combined". It means the process of borrowing has always been important in Russian, as well as in Soviet culture, urban space included (Paperny 2002: xxi). The combination should be decoded via philosophy of space.

\section{Estonian post-war town planning}

In the 1930s similarly to global tendencies (new tradition based town planning), architecture in independent Estonia started to focus on stately urban ensembles as an architectural element enabling the young country to develop its own stately façade. In order to tackle the dream central city spaces of Tallinn, Tartu, Pärnu and other towns were intended to be redesigned. The tendency increased as even Estonia became more 


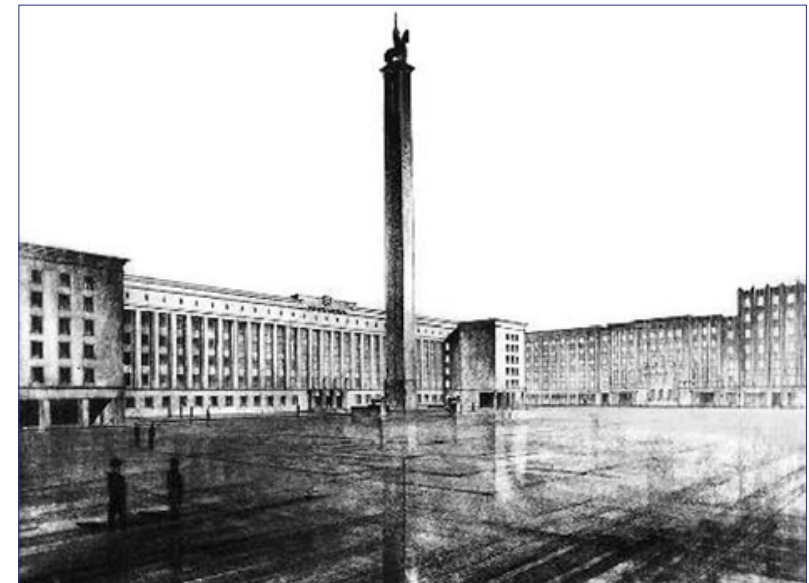

Fig. 1. Winning entry for Liberty Square in Tallinn, 1937, by Alar Kotli (EAM 2.1.203)

authoritarian. For instance, according to the president Konstantin Päts's decree of May 27th 1936 all façades in Tallinn Liberty Square district could be designed or redesigned with permission of the president only (Vabadussõja üleriikliku mälestusmonumendi püstitamise seadus 1936: 1028). The Tallinn Liberty Square city space architectural content was as an ebodyment of the new tendencies (Fig. 1).

The similar developments one can see both in the new business and transport centre of outskirt of Pärnu (started in 1939) (EAM 2.1.219) and in new institutional ensemble around the Tartu University in Tartu centre (started in 1939) (EAA 2100.6.163; Ülikooli ümbruse ... 1938). Neither of them had been finished due to beginning of Soviet occupation in 1940.

Stalinist principles brought by Soviet occupation since 1940 and again since 1944 seemed rather similar to local ones. But in in a couple of times Estonian architects and urban space practice faced quite unexpected instructions given by the occupying regime.

\section{Soviet town planning, socialist realism}

Due to ideological reasons private property was forbidden in the Soviet Union. Thus in comparison with other states it was easier to operate with town structure, to control society via urban space. It was especially crucial after World War II - necessity to restore wrecked towns gave a rare opportunity to celebrate victory of the regime and its ideology.

As stated the Communist Party of the Soviet Union's Central Committee's Plenum decided on June $15^{\text {th }}$, 1931 - town planning including both reconstruction and construction would be realized under the guidance of the state's central plan for the national economy (Bunin 1945: 290-291). Nearly a year later, in January 1932, the Soviet People's Commissar of Education
Anatoly Lunacharskiy stated that a task of architecture is to integrate functionality and utility in a harmonized way into an ideological idea (Kosenkova 2009: 19-20). In February 1932 the Soviet Communist Party found a new ideological method - socialist realism; the method was supposed to "embody an absolute apocalyptical future where the difference between past and future abolishes significance." (Groys 1998: 859). The method had to embrace literature, music, art, architecture.

In 1934 Soviet Writer's Union of the USSR formulated socialist realism as a method that demands artist to depict reality faithfully, historical events in explicit way within revolutionary development. The depiction had to be in tight connection with educating workers (Soviet citizens) in socialist spirit. Socialist realism as evolving and ambient category was intended to provide artist vast opportunities to choose different forms, styles and genres (ENE VII 1975: 243).

The first Stately Union Congress of Soviet Architects held within the period of June $16^{\text {th }}-$ June $26^{\text {th }}, 1937$, stated in the resolution that the principle method of Soviet architecture was socialist realism. According to the new method:

i. Soviet architect was supposed to be able to produce, in the utmost rapid and industrialized way, architecture that was highly qualified both aesthetically and economically (Capenko 1952: 74-75);

ii. It was imperative to create artistic image in order to educate and re-educate the masses. It was a synthesis of the arts under one architectural "roof" (Kodres 2008: 142);

iii. Architecture in a city space was supposed to be ensemble-like, where every house had to be ruled by ensemble. That meant a certain hierarchy where every part had to obey the principle of unity (Zholtovskij 1940).

After the World War II socialist realism was complemented with victory theme.

\section{Stalinist stately urban ensembles in Estonia: new policy}

In 1945 the head of the Stately Committee of Architecture of the USSR Arkadi Mordvinov formulated seven principle conditions of the Soviet post-war town planning that were compulsory for all architects:

1) town planning was supposed to be in tight connection with natural environment in order to expose its beauty;

2) town plan needed balanced compositional centre (for instance centre - main street railway station square);

3) monumental public buildings had to be erected in junctions; 
4) quarters of dwelling houses had to be planned in complex way and designed in one ensemble;

5) all buildings had to be painted only in light colours (dream of positive future);

6) rationality and high quality of structures and infrastructures (electricity, water supply etc.) were must;

7) thorough quality survey both in architects' projects and building process was inevitable (Kosenkova 2009: 42).

During World War II according to plenary resolution of the Soviet Architect's Union of the USSR the soviet architects were supposed to be ready to the gigantic restoration works after the war (Plenum ... 1943). The head of the Department of Architecture of the Estonian SSR Harald Arman residing in the USSR started to organise restoration of Estonian towns already in mid-1944 (Gorich 1946).

H. Arman gave local architects rather certain instructions for town planning in Estonian SSR. The instructions followed the board resolution of the Soviet Architect's Union of the USSR made on October $24^{\text {th }}$, 1946 and the plenary resolution of the Soviet Architect's Union of the USSR made on August $2^{\text {nd }}$ 1947. (Meigas 1948: 5-7; Arman 1946: 5-7; Tvorcheskie ... 1948: 4961; Arman 1948: 10-11).

In late $1947 \mathrm{H}$. Arman declared three principles concerning town centre planning:

1) proper town centre building plan;

2) strict regulation which buildings are supposed to be erected first;

3) "right" policy of town planning.
According to first principle $\mathrm{H}$. Arman suggested:

- not to demolish every building;

- meanwhile the future town centre had to have tight connection with streets (radiant gridline), the main square was supposed to look like dignified by its measurements and architectonical appearance, administrative buildings, public buildings;

- cultural objects had to be placed around central square and to be visible from every radiating street (Arman 1948: 10-11).

H. Armans principles were leaning on A. Mordvinovs seven principles and both of them were mandatory to be followed by local urban planners, architects.

\section{Implementation of the new policy}

\section{The new policy in Tallinn and Pärnu}

Stalinist stately urban ensembles in Estonia provided an opportunity for architects to carry out some of their megalomaniac architectural ideas from the period of independence. On the one hand, Estonian mid 1940s town planning was quite similar to the pre-war independence period disregarding the rest of the Soviet Union architecture (Fig. 2). On the other hand, some architects (Voldemar Meigas, Otto Keppe) proposed to restore Tallinn centre similarly to Stalinist practice in Leningrad (St. Petersburg). Architect H. Arman balanced between two tendencies. Meanwhile East Estonian industrial towns Sillamäe and Kohtla-Järve were designed mostly under the guidance of Leningrad construction departments.

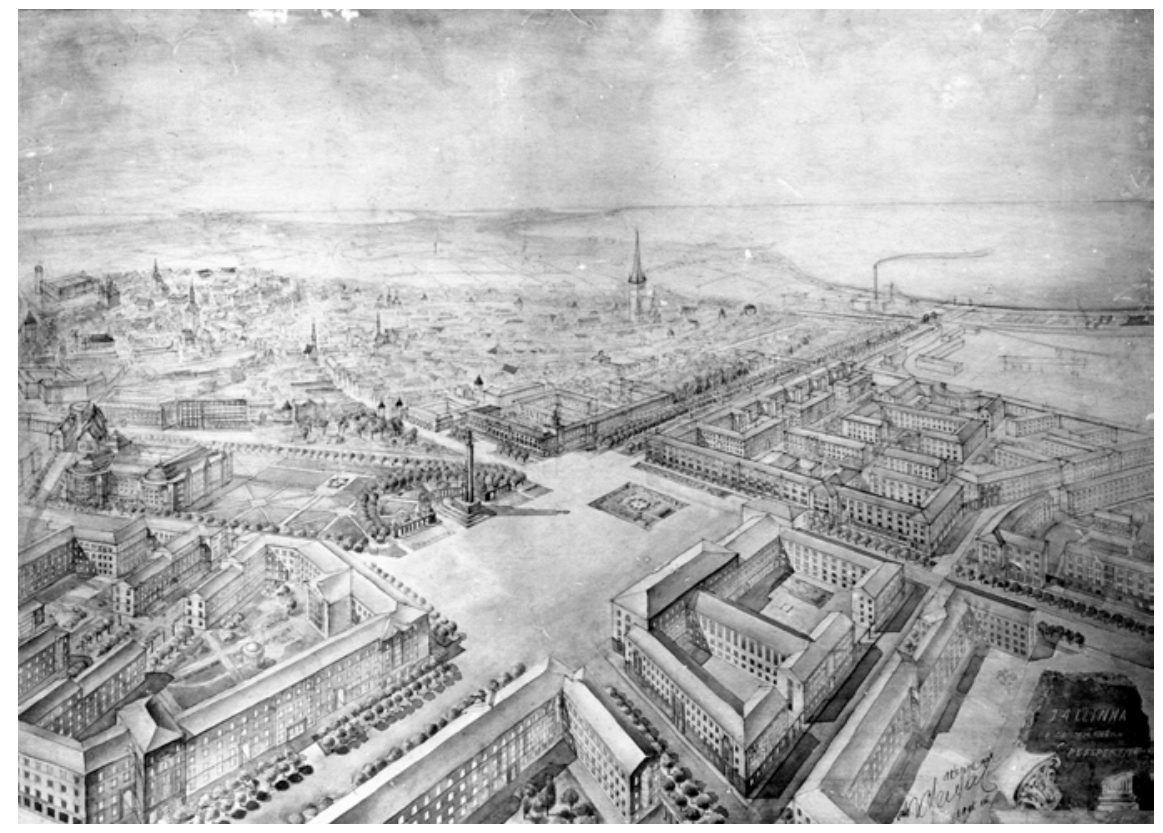

Fig. 2. Entry for Central Square in Tallinn, 1945 by Harald Arman, Voldemar Meigas, Otto Keppe (EAM 18.4.8) 


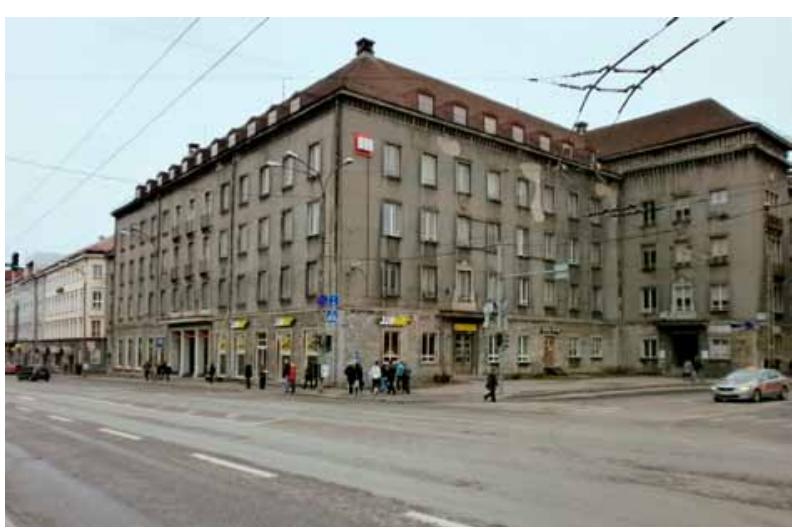

Fig. 3. Estonia Boulevard administrative buildings in Tallinn from the turn of 1940s and 1950s. City space by Harald Arman, the front building by Enn Kaar (Photo: Siim Sultson, 2014)

In 1940s local Estonian architects used to design administrative and apartment buildings in 1930s manner: granite wall coating, modest, scarce ornament, only roofs were a bit more pitched and some soviet symbols were added (Fig. 3)

For example, the new centre of Tallinn consisting of the Tallinn Cultural Centre in front of Estonia theatre and the Central Square was designed under the guidance of $\mathrm{H}$. Arman in the quite same way. According to the masterplan of Tallinn (H. Arman) the Central Square was designed in the junction of Pärnu Road, Tartu Road, Narva Road and Mere Boulevard. On the opposite of the converging streets an esplanade was designed between the square and national opera (the Estonia theatre). The square itself was planned to be surrounded by several office and ministry buildings. The Cultural Centre was intended to concentrate universities, libraries and other both academic and cultural institutions together around the boulevard-like crossing axes in front of the Estonia theatre (Fig. 4). Whole the complex was supposed to be as representative as possible, as an example of implementation of Stalinist principles in town planning (Arman 1948: 10 -11, 1950: 9-12).

However, unlike the rest of the Soviet Union Estonian 1940s masterplans tried to match with gridline and appearance of the existing town (ERA.R-1992.2.33: 88-92).

So-called liberal Stalinism ended in 1949 while approximately 20000 inhabitants of Estonia were deported to Siberia within one night. Political pressure radiating from Moscow compelled local Estonian architects to design city space more similarly to the capital of USSR, Leningrad (St. Petersburg), Stalingrad (Volgograd). On October $25^{\text {th }}-28^{\text {th }}, 1950$ the plenary session of the Soviet Architect's Union of the USSR was dedicated to architects' creative tasks within "the grandiose fifth Stalin five-year plan". According to the plenary session resolution the Soviet architects were supposed to be more active, creative and ideologically aware, dedicated to socialist realism, innovative and to use more classicist heritage (Tvorcheskie ... 1951: 5, 7-32, 108-117). According to the board resolution of the Soviet Architect's Union of the USSR made on June $5^{\text {th }}, 1952$ certain instructions in the field of ensemble-like town planning such as for Moscow,

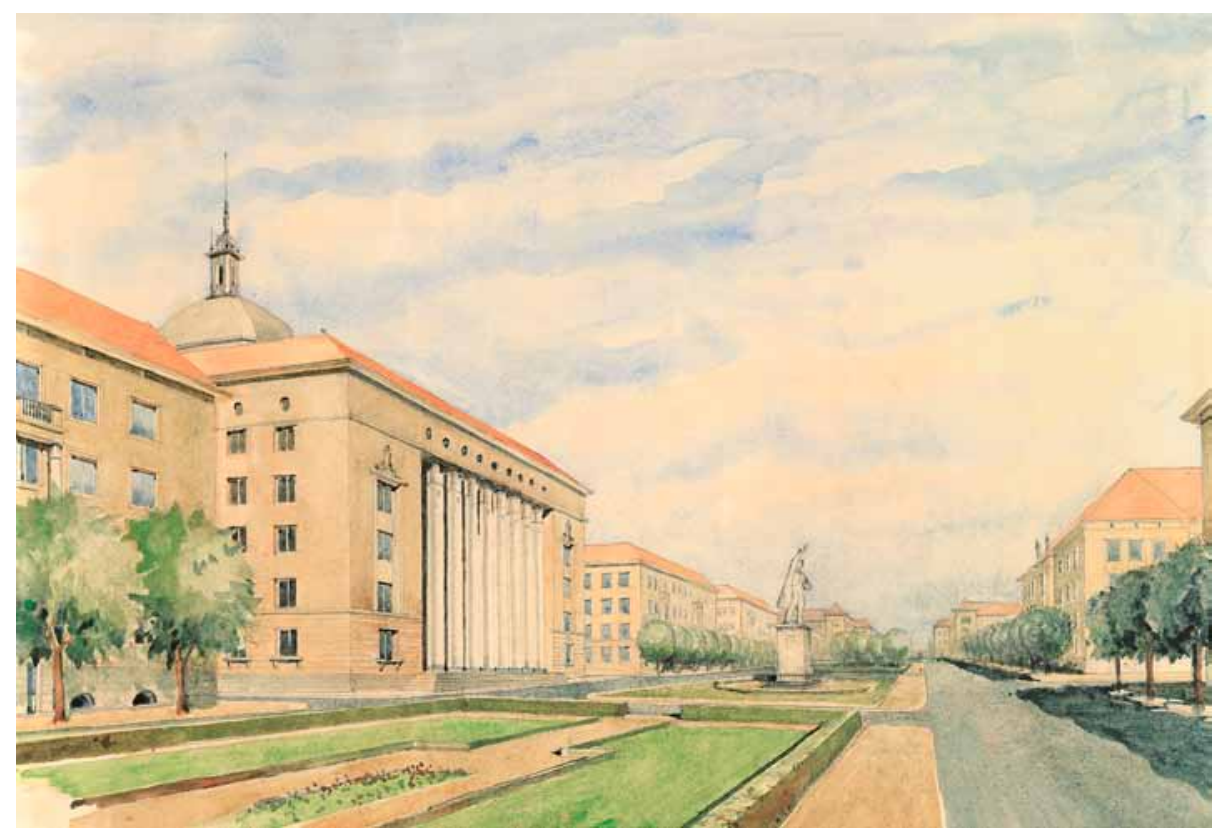

Fig. 4. Entry for the Cultural Centre Square in Tallinn, 1947 by Harald Arman (EAM 3.1.164) 


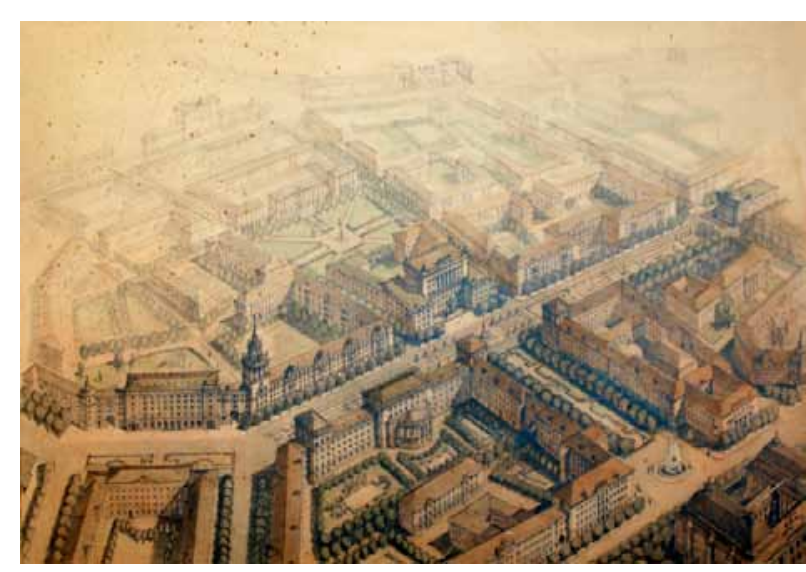

Fig. 5. Design for the Cultural Centre in Tallinn, 1953 by Harald Arman (EAM 3.1.32)

Leningrad, Stalingrad, Kiev, Minsk - those were model towns, e.g. set as an example to other towns all over the Soviet Union (Hronika. XIV plenum Pravlenija ... 1952: 31-33). Results of the increased politivcal pressure and the results can be seen in new design of Tallinn Cultural Centre (Fig. 5).

Perhaps one of the most Estonian enterprising town planning treatments took place in Pärnu. In 1947 and 1948 E. Arman's restoration project for Pärnu was accepted in the Department of Architecture of the Estonian SSR (ERA.R-1992.2.1:45-8; ERA.R-1992.2.33: 74-84). At the same time the project passed by the expertise made by the consultant for the Estonian SSR of Soviet Academy of Architecture Igor Fomin to change the project (ERA.R-1992.2.33: 139-142). By the end of 1949 and the beginning of 1950 the Department of Architecture of the Estonian SSR merely accepted the consultant's proposals (ERA.R-1992.2.33: 104-126).

In summer $1952 \mathrm{H}$. Arman itself proposed (with Grigory Schumovskiy and Mart Port) a project for Pärnu. The partly realized town planning project followed I. Fomin's suggestions. E. Arman's project was rejected. According to $\mathrm{H}$. Arman's project many quarters of the burnt but still preserved old town were demolished, the St. Nicholas Church (14th century) in the same condition was exploded. The central square from 1930s was abandoned, the town got for its measures enormous new axial centre. The new centre was orientated via bridge to main entrance road from Tallinn. In order to get necessary space for the centre $1 / 3$ of mediaeval old town quarters and ruins of the Teutonic Castle were demolished. One of the reasons of such large-scale changes was caused by the fact that in 1952 Pärnu became a future oblast capital. Similarly, to Tallinn and Tartu importance of Pärnu increased. That was caused by replacement of fifteen traditional counties with three Soviet oblasts by Moscow (ERA.R-1992.2.70: 47; ERA.R-1992.2.33: 42-4).

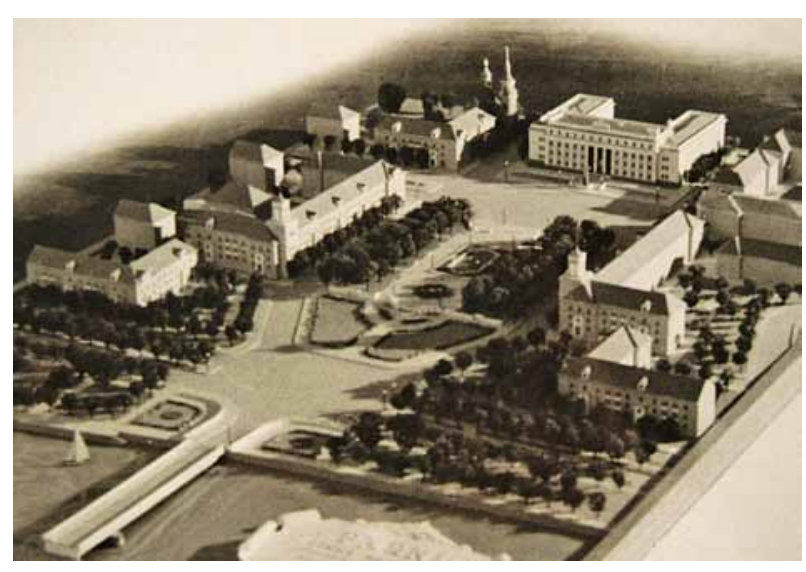

Fig. 6. Pärnu oblast centre by Harald Arman, 1952-1955. On the site of the demolished Old Town and ruins of the Teutonic Castle (EAM 3.1.323)

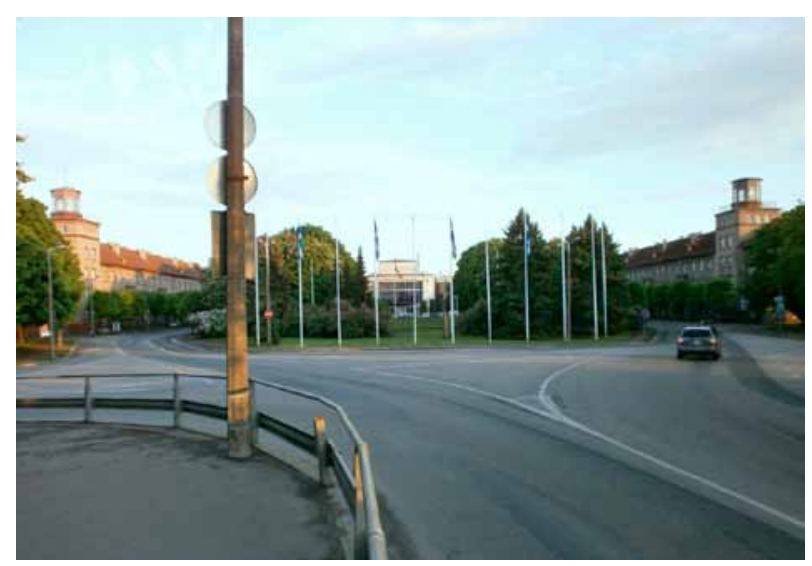

Fig. 7. Pärnu oblast centre (Vasa park) nowadays (Photo: Siim Sultson, 2013)

Since Pärnu was regarded as a future oblast capital it got rather grandiose centre plan. While the soviet architect's handbook (1952) suggested to design a 1-hectare central square for the town with the population of 50000 , Pärnu with the population of 20000 got a 2.5-hectare central square (Kratkij ... 1952: 20-21) (Figures 6, 7).

Both centres designed under the guidance of $\mathrm{H}$. Arman have compositional similarities with Moscow southwest axis (Tallinn: if to prolong axis of the Cultural Centre to south), St. Petersburg Moscow Prospect (Tallinn, Pärnu), Kiev Kreshchatyk (Tallinn, Pärnu).

\section{The new policy and the Estonian Stalinist industrial towns Sillamäe and Kohtla-Järve}

Rather similar anomalies between the amount of population and the area of town centre could be noticed in East Estonian industrial towns Sillamäe and KohtlaJärve designed under the guidance of Lengiproshacht and Lengorstroyproyekt residing in Leningrad (St. Petersburg). In comparison with the rest of Estonian towns Sillamäe and Kohtla-Järve may be regarded as 
newly designed towns. Nevertheless, both of them had got small and widely dispersed settlement before the Soviet time. In 1940s-1950s Sillamäe and Kohtla-Järve were designed to be new industrial towns. Unlike the rest of Estonian towns inhabitants of Sillamäe and Kohtla-Järve were deported from the large Soviet Union. While Kohtla-Järve was regarded as oil-shale mining and processing complex, Sillamäe was classified town due to processing of uranium oxides. By 1950s both towns with the population of 10000 got

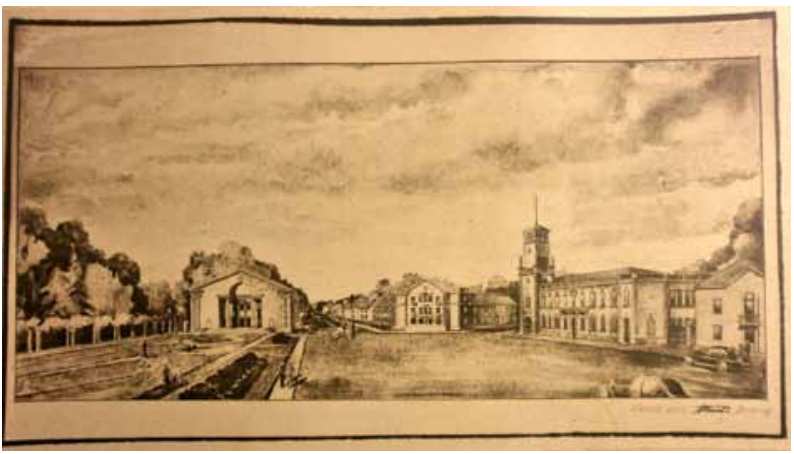

Fig. 8. Design for Stalinist centre of Sillamäe, 1948 by Lengiproshacht (Sillamäe Muuseum)

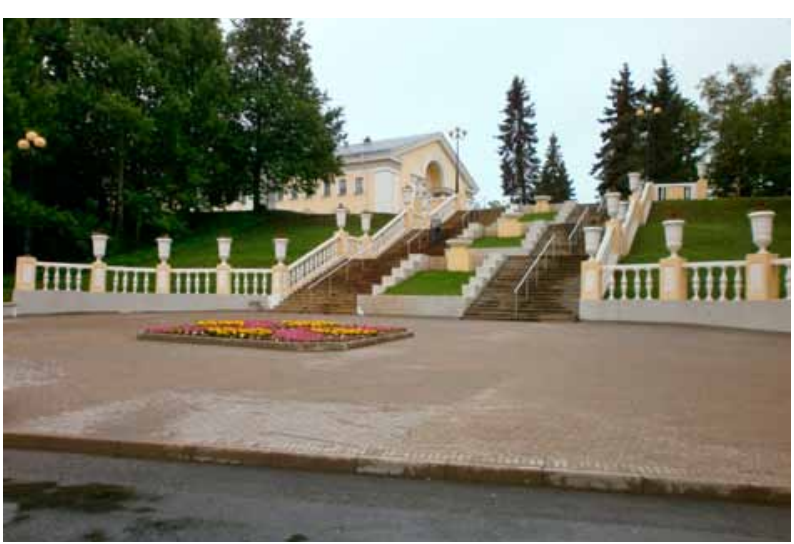

Fig. 9. Stalinist centre of Sillamäe, staircase, early 1950 s by Lengiproshacht (Photo: Siim Sultson, 2013)

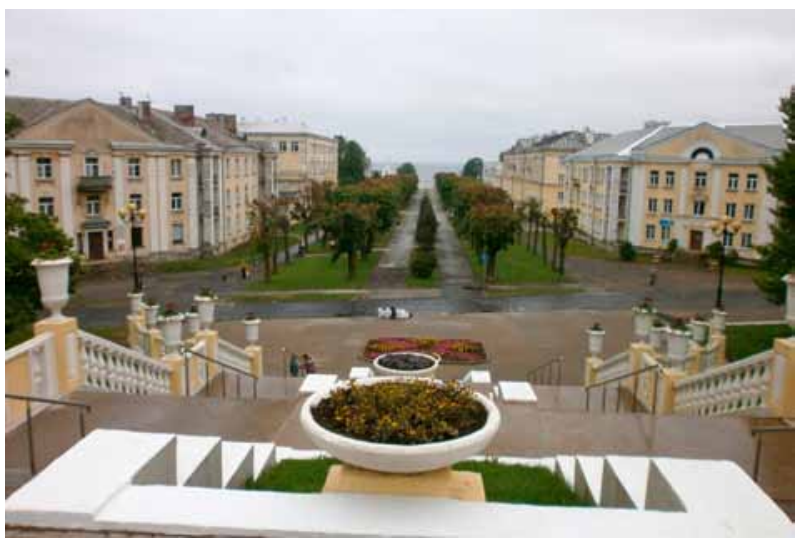

Fig. 10. Stalinist centre of Sillamäe, staircase axis, early 1950s by Lengiproshacht (Photo: Siim Sultson, 2013) practically as large representative centres as one may meet in Pärnu.

Representative centre of Sillamäe consists of three main streets crossing central square and recreational area. While the streets are being situated onto two coastal levels, the crossing and sea-orientated recreational area connects the levels with a staircase ( $\dot{a} l a$ Stalingrad) (ERA.R-1992.2.12) (Figs 8, 9).

In Kohtla-Järve the central boulevard that (50 meters wide) connects the house of culture and the central cinema is crossed by axis of complex of local government (ERA.R-1992.2.57; ERA.R-1992.2.41) (Figs 5, 11, 12, 13).

Although East Estonian industrial towns are planned mostly by non-local architects (especially Sillamäe), for instance Stalinist central gridline of Kohtla-Järve has much in common with Stalinist central gridlines of Tallinn and Pärnu. While the whole centre of Sillamäe (especially the part with staircase axis) has many compositional similarities with Stalingrad (for example staircase axis), the low level of the town (between sea and staircases) has some similarities with Tallinn and Pärnu Stalinist centres (Figs 10, 11, 12).

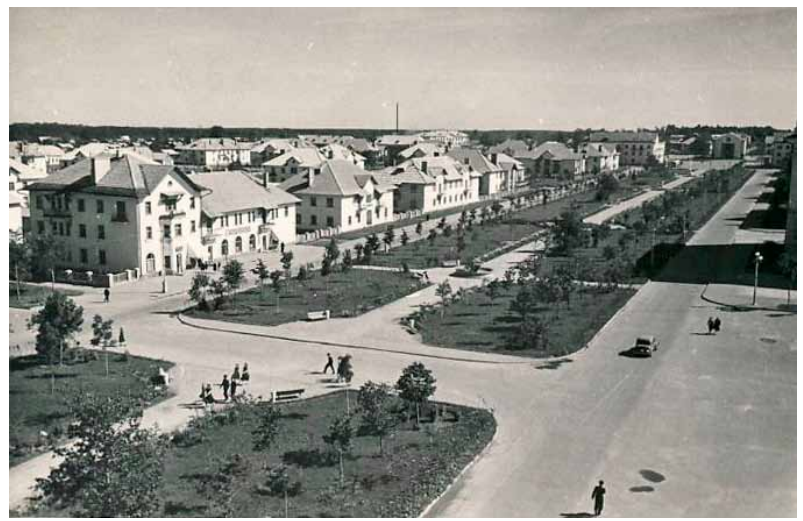

Fig. 11. Stalinist centre of Kohtla-Järve, early 1950s by Lengorstroyproyekt. Photo taken in 1950s (RM F 646.176)

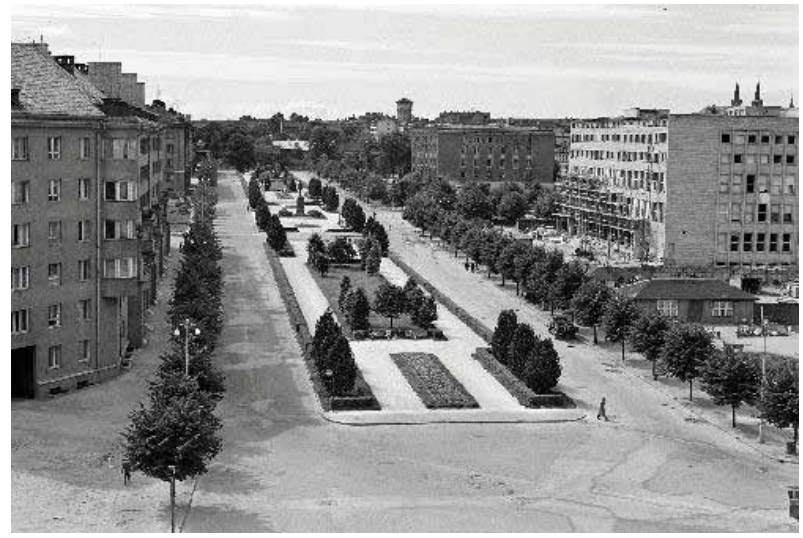

Fig. 12. The Cultural Centre in Tallinn, early 1950s. Photo taken in 1961 (EFA 209.1-3509) 


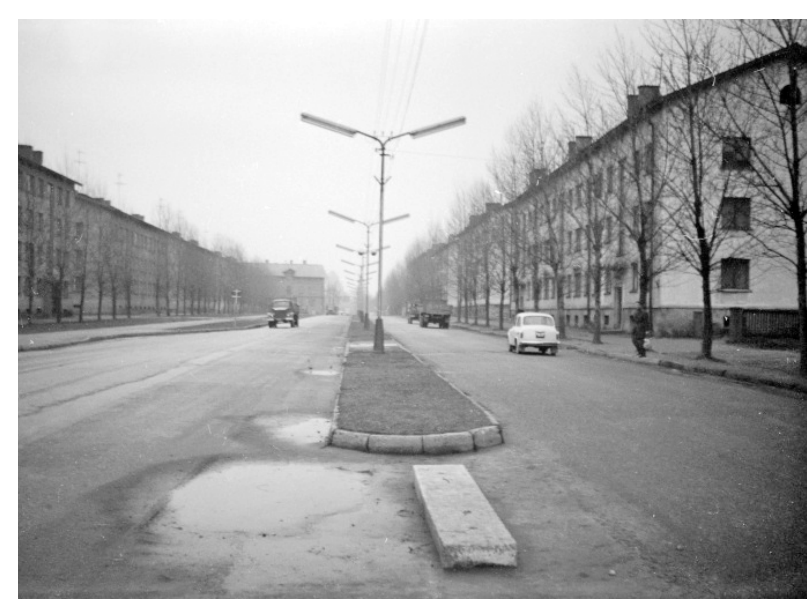

Fig.13. Pärnu oblast centre in mid1960s (EAM AM N 21975:1)

Kohtla-Järve centre (the boulevard and the crossing axis) is compositionally rather similar to the Tallinn Cultural Centre and Pärnu oblast centre (Figs 4, 13, $14,15)$.

While in Kohtla-Järve and Sillamäe one can regard as new towns, established during Stalin era, the same attempts (to establish something new) may be seen both in Tallinn and Pärnu, as well. East Estonian industrial towns (Sillamäe and Kohtla-Järve) got axially arranged representative, perspective plans. Kohtla-Järve and Sillamäe one can regard as new towns, established during Stalin era, the same attempts may be seen both in Tallinn and Pärnu, as well.

\section{Conclusions}

According to the political (above stated principles), administrative (above mentioned activity of the Department of Architecture of the Estonian SSR) and compositional reasons under-researched EastEstonian Stalinist industrial towns Kohtla-Järve and Sillamäe have architectural and urban compositional similarities and connections with Stalinist centres of Tallinn and Pärnu.

On the basis of abovementioned architectural policy principles and urban compositional statements one can derive five principles characterising Estonian PostWar Town Planning Principles:

1. Unification of urban space. Abundance of traditional locus, rejection of any attempt to restore wrecked city centres, compel to follow the Soviet town planning doctrine by concept, forms and building materials, if necessary replacement of city and its inhabitants.

2. Strict urban gridline and urban space as an ideology support. Shift of functional

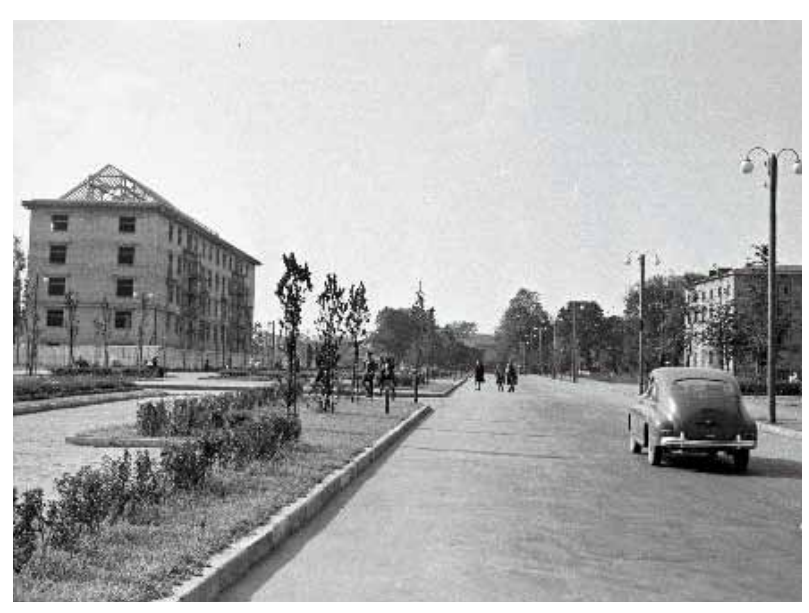

Fig. 14. The Cultural Centre in Tallinn, early 1950s. Photo taken in early 1950s (EFA 335.0-70335)

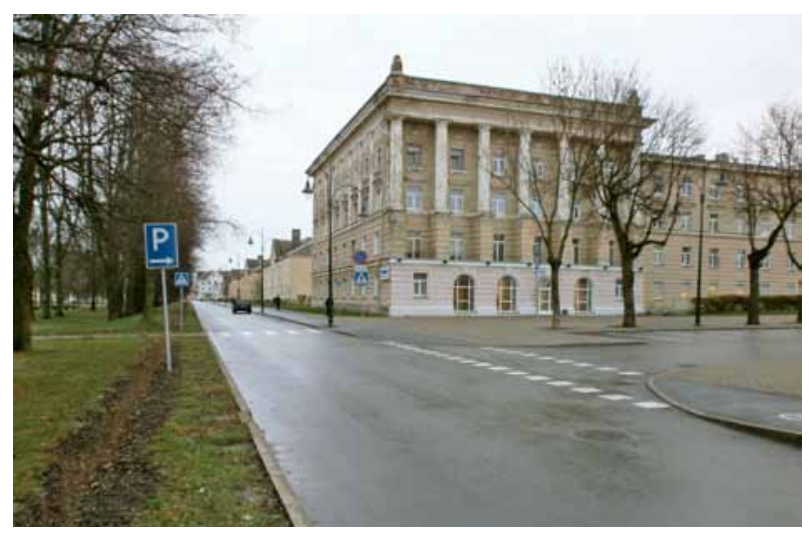

Fig. 15. Stalinist centre of Kohtla-Järve, early 1950s by Lengorstroyproyekt (Photo: Siim Sultson, 2013)

and ideological reason. Symbols. Stately urban ensemble has always been supposed to embody dignity, power, harmony of society, to monumentalize the latter one. See Henry Lefebvre's triad (Representational Space Representation of Space - Spatial Practice) (How to perceive, how to concieve).

3. Intensifying of public city space. The city space was supposed to be efficient, functional, strict, axial, perspective.

4. Dominant public space. Stressed ideology, new memory. Cult of bright future.

5. Officially approved examples. Model towns, set as examples to other towns all over the Soviet Union (Moscow, Leningrad/ St. Petersburg, Stalingrad/Volgograd, Kiev, Minsk), Classicism (esp. Russian classicism), Cinquecentto, Roman antique.

Consequently, taking into account all abovementioned aspects of the current paper East-Estonian Stalinist 
industrial towns Sillamäe and Kohtla-Järve are supposed to be included and incorporated into research of Estonian post-war Stalinist urban space as inseparable issues of research.

\section{References}

Arman, H. 1946. Linnade planeerimise küsimusi ENSV-s [Problems Concerning Town Planning in Estonian SSR]. ENSV Arhitektide almanahh 1946, 5-8. (in Estonian)

Arman, H. 1948. Detailplaneerimise küsimusi [Problems Concerning Detailed Planning]. ENSV Arhitektide Almanahh 1947, 10-17. (in Estonian)

Arman, H. 1949. Tallinna kultuurikeskuse detailplaneerimine [Detailed Planning of the Tallinn Cultural Centre]. ENSV Arhitektide Almanahh III, 25-29. (in Estonian)

Arman, H. 1950. Tuleviku-Tallinn. Eesti NSV Poliitiliste ja Teadusalaste Teadmiste Levitamise Ühing 1 (45) [Future Tallinn. Society for Spreading of Knowledge of Politics and Science 1 (45)]. Tallinn: Eesti Riiklik Kirjastus. (in Estonian)

Arman, H; Starostin, I. 1951. Arhitektuurialastest saavutustest ja ülesannetest Nõukogude Eestis [About Achievements and Tasks of Architecture in Soviet Estonia]. ENSV Arhitektide Almanahh IV, 7-8. (in Estonian)

Arman, H. 1955. Voprosy planirovki i zastrojki centra Tallina [Questions Concerning Planning and Building-up of Tallinn]. Problemy sovetskogo gradostroitel'stva 5, 49. (in Russian)

Bruns, D. 1993. Tallinn: linnaehituslik kujunemine [Tallinn: Urban Formation]. Tallinn: Valgus. (in Estonian)

Bunin, A. V. 1945. Gradostroitel'stvo [Town Planning]. Moscow: Izdatel'stvo Akademii Arhitektury SSSR. (in Russian)

Capenko, M. R. 1952. O realicticheskih osnovah Covetskoj arhitektury [About Realistic Principles of Soviet Architecture]. Moscow: Gosudarstvennoe izdatel'stvo literatury po stroitel'stvu i arhitekture. (in Russian)

Cinis, A.; Drèmaitè, M.; Kalm, M. 2008. Perfect representations of Soviet planned space. Mono-industrial towns in the Soviet Baltic Republics in the 1950s-1980s, Scandinavian Journal of History 33 (3): 226-246.

http://dx.doi.org/10.1080/03468750802079409

EAA.2100.6.163. Ülikooli asutuste väljaarendamise ja ehitamise kava [Plan of development and building for the departments of the university]. Eesti Ajalooarhiiv [Estonian Historical Archives] (EAA). (in Estonian)

EAM 2.1.203 Tallinna Vabaduse väljaku kujundamise võistlustöö, I auhind, perspektiivvaade [Winning entry for Liberty Square in Tallinn, perspective view]. Eesti Arhitektuurimuuseum [Museum of Estonian Architecture] (EAM). (in Estonian)

EAM 18.4.8 Tallinna Keskväljaku perspektiivvaade, 1945 [Perspective view of Central Square in Tallinn]. Eesti Arhitektuurimuuseum [Museum of Estonian Architecture] (EAM). (in Estonian)

EAM 3.1.164 Tallinna Kultuurikeskus, perspektiivvaade piki Lenini puiesteed, 1947 [Cultural Centre in Tallinn, perspective view along Lenin Boulevard, 1947]. Eesti Arhitektuurimuuseum [Museum of Estonian Architecture] (EAM). (in Estonian)
EAM 3.1.32 Tallinna Kultuurikeskus, perspektiivvaade õhust, 1953 [Cultural Centre in Tallinn, aerial perspective view, 1953]. Eesti Arhitektuurimuuseum [Museum of Estonian Architecture] (EAM). (in Estonian)

EAM 2.1.219 Pärnu esindusliku linnaosa kujundamise eelprojektide võistluse tingimused, 1938 [Terms for entries concerning Pärnu representative centre, 1938]. Eesti Arhitektuurimuuseum [Museum of Estonian Architecture] (EAM). (in Estonian)

EAM 3.1.323 Pärnu oblastikeskus, maketivaade [Pärnu oblast centre, the model view]. Eesti Arhitektuurimuuseum [Museum of Estonian Architecture] (EAM). (in Estonian)

EAM AM N 21975:1 Fotonegatiiv: V. I. Lenini nimeline puiestee Pärnus [Photo negative: V. I. Lenin Boulevard in Pärnu]. Eesti Ajaloomuuseum [Estonian History Museum] (EAM AM). (in Estonian)

Ederberg, E. 1946. Tähtsamad sõja ajal hävinud arhitektuuri ja kunsti muinsusesemed Eesti ENSV-s [The Main Objects and Architecture That Had Been Destroyed in the War]. ENSV Arhitektide Almanahh 1946, 59-63. (in Estonian)

Ederberg, E. 1948. Narva vanalinna ülesehitamise probleeme [Problems Concerning Restoration of Old Town of Narva]. ENSV Arhitektide Almanahh 1947: 60-65. (in Estonian)

Eesti arhitektuuri ajalugu [History of Estonian Architecture]. 1965. Tallinn: Eesti Riiklik Kirjastus. (in Estonian)

EFA 209.1-3509 Vaade Lenini puiesteele [View at Lenin Boulevard]. Eesti Filmiarhiiv [Estonian Film Archives] (EFA). (in Estonian)

EFA 335.0-70335 Vaade Lenini puiesteele [View at Lenin Boulevard]. Eesti Filmiarhiiv [Estonian Film Archives] (EFA). (in Estonian)

ENE - Eesti nõukogude entsüklopeedia [Estonian soviet encyclopaedia] VII. 1975. Tallinn: Valgus, 243. (in Estonian)

ERA.R-1992.2.1. Kohtla-Järve generaalplaan ja projektid,1945 [Masterplan and projects for Kohtla-Järve, 1945]]. Eesti Riigiarhiiv [Estonian State Archives] (ERA). (in Estonian)

ERA.R-1992.2.12. Sillamäe objektide projektid: generaalplaan,1946 [Projects of objects in Sillamäe: masterplan, 1947]]. Eesti Riigiarhiiv [Estonian State Archives] (ERA). (in Estonian)

ERA.R-1992.2.22. Kohtla-Järve objektide projektid: generaalplaan,1947 [Projects of objects in Kohtla-Järve: masterplan, 1947]]. Eesti Riigiarhiiv [Estonian State Archives] (ERA). (in Estonian)

ERA.R-1992.2.31. Kohtla-Järve objektide projektid: generaalplaani skeem,1948 [Projects of objects in Kohtla-Järve: scheme for masterplan, 1948]. Eesti Riigiarhiiv [Estonian State Archives] (ERA). (in Estonian)

ERA.R-1992.2.33. Narva objektise projektid: generaalplaan, 1948 [Projects of objects in Narva: masterplan, 1948]. Eesti Riigiarhiiv [Estonian State Archives] (ERA). (in Estonian)

ERA.R-1992.2.41. Kohtla-Järve Võidu bulvari ehitusprojekt, 1949 [Construction project for Victory boulevard in KohtlaJärve, 1949]. Eesti Riigiarhiiv [Estonian State Archives] (ERA). (in Estonian)

ERA.R-1992.2.57.Kohtla-Järve objektide projektid: kultuuri- ja puhkepark, peaväljak, 1951 [Projects of objects in KohtlaJärve: park for culture and recreation, central square, 1951]. Eesti Riigiarhiiv [Estonian State Archives] (ERA). (in Estonian) 
ERA.R-1992.2.70. Kohtla-Järve keskväljak, 1952 [Central Square in Kohtla-Järve, 1952].Eesti Riigiarhiiv [Estonian State Archives] (ERA). (in Estonian)

Foucault, M. 2000a. Different spaces, aesthetics. Essential works of Michael Foucault 1954-1984. London: Penguin Books, 175-185.

Foucault, M. 2000b. Space, knowledge, and power. Essentsial works of Michael Foucault 1954-1984. London: Penguin Books, 349-364.

Gorich, I.1946. V masterskoj zodchego [In Architect's Atelier]. Sovetskaja Estonija, August $10^{\text {th }}$. (in Russian)

Goodman, N. 1985. How buildings mean, Critical Inquiry 11(4): 642-653. http://dx.doi.org/10.1086/448311

Groys, B. 1998. Stalin-stiil [Stalin-style], Akadeemia 4: 855-891. (in Estonian)

Haljak, L.1949. Projektide võistlused 1947. aastal [Contests of Projects in 1947]. ENSV Arhitektide Almanahh III, 52-70. (in Estonian)

Härmson, P. 1983. Pärnu keskuse planeerimiskava kujunemine [Development of Planning Project of Pärnu Centre], Ehitus ja Arhitektuur 3: 31-43. (in Estonian)

Hronika. XIV plenum Pravlenija Sojuza sovetskih arhitektrov [Chronicle. XIV Plenum of the Union of Soviet Architects]. 1952. Arhitektura SSSR 7, 31-33. (in Russian)

Kalm, M.1994. Arhitekt Alar Kotli [Architect Alar Kotli]. Tallinn: Kunst. (in Estonian)

Kalm, M. 2001. Eesti 20. sajandi arhitektuur. Estonian 20th century architecture. Tallinn: Prisma Prindi Kirjastus. (in Estonian)

Kalm, M. 2003. The sovietization of Baltic architecture, Yhdyskuntasuunnittelu [The Finnish Journal of Urban Studies] 41(3): 42-51.

Keppe, O. 1951. Kokkuvõte Üleliidulise Arhitektide Liidu pleenumi ja EN Arhitektide Liidu konverentsi tööst [Summary of Work concerning Plenum of the All-Union Architect's Union and Conference of the Union of Soviet Estonian Architects]. ENSV Arhitektide Almanahh IV, 66-70. (in Estonian)

Kodres, K. 2008. Sovietization of classical architecture: the case of Estonia. Quo vadis architectura? Architectural tendencies in the late 1930s, 1940s, and the early 1950s. Helsinki: University of Technology, 130-151.

Kosenkova, J. L. 2009. Sovetskij gorod 1940-h-pervoj poloviny 1950-h godov. Ot tvorcheskih poiskov k praktike stroitel'stva. Izd. 2-e, dop. [Soviet Town from 1940s to the First Half of 1950s. From the Creative Searches to the Practice of Building. Ed. 2, Amended]. Moscow: Knizhnyj dom "LIBROKOM". (in Russian)

Kratkij sppavochnik arhitektora [Short Regulations for Architect]. 1952. Moscow: Gosudarstvennoe izdatel'stvo literatury po stroitel'stvu i arhitekture. (in Russian)

Lankots, E. 2004. Klassid klassideta ühiskonnas: Elitaarne ruumimudel EestiNSV-s ja nomenklatuursed korterelamud Tallinnas 1945-1955 [Classes in Society Without Classes: Elitist Model of Space in Estonian SSR and apartments of nomenklatura in Tallinn in 1945-1955], Kunstiteaduslikke uurimusi / Studies on Art and Architecture/ Studien für Kunstwissenschaft 2: 11-41. (in Estonian)

Lefebvre, H. 1991. The production of space. Oxford: Cambridge

Meigas, V. 1948. Eesti NSV arhitektide loomingulised ülesanded [Creative Tasks of the Architects of Estonian SSR]. ENSV Arhitektide Almanahh 1947, 5-9. (in Estonian)
Meigas, V. 1949. Tallinna keskväljaku project [Project of the Tallinn Central Square]. ENSV Arhitektide Almanahh III, 20-24. (in Estonian)

Orlova, M. 2003. Stalinistlik arhitektuurikorraldus Eestis 1944-1955: Magistritöö [Stalinist organization in Estonia in 1944 - 1955. Master's Thesis]. Tallinn: Eesti Kunstiakadeemia [Estonian Academy of Arts]. (in Estonian)

Paperny, V. 2002. Architecture in the age of Stalin: culture two. Cambridge: University Press.

Plenum pravlenija Sojuza arhitektrov [Plenum of the Board of the Union of Soviet Architects]. 1943. Pravda, August 19 $9^{\text {th }}$. (in Estonian)

RM F 646.176 Kohtla-Järve Võidu puiestee [Victory Boulevard in Kohtla-Järve]. Virumaa Muuseumid [Virumaa Museums]. (RM F) (in Estonian)

Sillamäe Keskuse perrspektiivvaade, kavand, 1948 [Perspective view of Sillamäe centre, draft, 1948]. Sillamäe Muuseum [Sillamäe Museum]. (in Estonian)

Soans, A.; Keppe, O. 1946. Tallinna linna uuest planeerimise kavast [About New Masterplan of Tallinn]. ENSV Arhitektide Almanahh 1946, 9-20. (in Estonian)

Soans, A. 1949. Pärnu arenemine kuurortlinnaks [Development of Pärnu to Resort]. ENSV arhitektide almanahh III, 30-35. (in Estonian)

Sultson, S. 2002. Staliniaegse esindusliku linnaansambli teostamine Eestis ja Harald Armani osa selles: Magistritöö [The Implementation of Stalinist Stately Urban Ensembles in Estonia, and the Role of Harald Arman. Master's Thesis]. Tallinn: Tallinna Pedagoogikaülikool. (in Estonian)

Sultson, S. 2003. Ideoloogilised jõujooned Eesti Stalini-aegses esinduslikus linnaansamblis [Ideological Impacts in Estonian Stalinist Representative Urban Ensemble]. Aeg ja lugu: Esseid eesti kultuuriloost. (Scripta ethnologica, 5.) Tallinn: Ajaloo Instituut, 98-109. (in Estonian)

Sultson, S. 2013. Kuidas Eesti arhitektil tuli planeerida "õigesti" ja unustada "vale". Eesti linnaruumi kujundamisest aastail 1944-1955 [Hoe Estonian Architect was compelled to plan in "right way" and to forget "the wrong"], Akadeemia 12: 2248-2277. (in Estonian)

Sultson, S. 2014a. Stalinization of Estonian city space: development, typology and perspectives, in International Conference 20th Century New Towns. Archetypes and Uncertainties, 22-24 May, 2014, Escola Superior Artística do Porto, Porto, Portugal, 368-384.

Sultson, S. 2014b. Is effective and enterprising state democratic? Town planning as an indicator of social effectiveness, in 2nd Annual Entrepreneurship Conference Innovation and Entrepreneurship: New Ways of Thinking. Conference Proceedings. Tallinn: Eesti Ettevõtluskõrgkool Mainor, $14-25$.

Sultson, S. 2015. The Stalinisation of Estonian town planning: visions and heritage, in session M50Urban Design for Mussolini, Stalin, Salazar, Hitler and Franco During the Interwar Period: Cities in Europe, Cities in the world12th International Conference on Urban History. Portugal, Lisbon, 3-6 September 2014. Ed. C. von Oppen, H. Bodenschatz, P. Sassi, M. Welch Guerra. Weimar: BauhausUniversität Weimar, 1-13.

Tvorcheskie zadachi sovetskih arhitektorov $v$ pjatiletnem plane vosstanovlenija i razvitija narodnogo hozjajstva. Materialy XII plenuma Sojuza sovetskih arhitektorov SSSR [Creative Tasks for Soviet Architects within the Five Year Plan of Restoration and Development of Peoples' Economy. Materials of the XII Plenum of the Union of Soviet 
Architects of USSR].1948. Moscow: Gosudarstvennoe izdatel'stvo arhitektury i gradostroitel'stva. (in Russian)

Tvorcheskie zadachi sovetskih arhitektorov $v$ pjatiletnem plane vosstanovlenija i razvitija narodnogo hozjajstva. Materialy XIII plenuma Sojuza sovetskih arhitektorov SSSR [Creative Tasks for Soviet Architects within the Five Year Plan of Restoration and Development of Peoples' Economy. Materials of the XIII Plenum of the Union of Soviet Architects of USSR].1951. Moscow: Gosudarstvennoe izdatel'stvo arhitektury i gradostroitel'stva. (in Russian)

Ülikooli ümbruse uus pale [New Appearance of Surrounding of the University]. 1938. Postimees, September $11^{\text {th }}$. (in Estonian)

Vabadussõja üleriikliku mälestusmonumendi püstitamise seadus [Law Concerning Erection of Monument of the War of Independence]. 1936. Riigi Teataja, 47(371): 1028. (in Estonian)
Volkov, L. 1991. Eesti Arhitektuurist aastail 1940-1954 [About Estonian Architecture within 1940-1954]. Linnaehitus ja Arhitektuur, Tallinn. Tallinn: Ehituse Teadusliku Uurimise Instituut, 183-213. (in Estonian)

Zholtovskij, I. V. 1940. Ancambl' v arhitekture [Ensemble in Architecture]. Stroitel'naja gazeta, May $30^{\text {th }}$. (in Russian)

\section{SIIM SULTSON}

is a PhD student in Tallinn University of Technology. He has worked as a lecturer and an Associate Professor of Art History since 2000. His field of research and research interests are Estonian 20th century interwar, post-war architecture, urban planning, urban space; living space on the background of Soviet interwar and post-war urban planning and German interwar urban planning, Stalinist urban ensembles in northeastern Estonian cities: determination, typology and potential as factors of the cities spatial development. 